\title{
The Showras in the Iranian Revolution
}

\author{
Labour Relations and the State in the Iranian Oil Industry, 1979-82
}

Peyman Jafari

"We snatched freedom, and we won't lose it soon", an Iranian oil worker exclaimed six weeks after the Pahlavi monarchy was overthrown in February 1979. ${ }^{1}$ Although oil workers had not participated in the initial stages of the revolutionary mobilization, their strikes had paralyzed the state and injected a sense of strength and viability into the revolutionary movement. After the fall of the monarchy, the strike committees in the oil industry and some other industrial sectors developed into showras (councils) - workplace committees through which workers made collective decisions and gained, or attempted to gain, control over production and the management of their workplace. Therefore, the showras became an important part of the political power struggle that emerged in 1979, and reflected the radical reimagining of social and political possibilities among significant sections of the urban workforce. Workers' initial perception that they had "snatched freedom" did not last long, however, as the showras were gradually side-lined, repressed and finally banned as independent organizations.

Despite their importance during revolutionary upheavals, the history of grassroots organizations such as the showras has remained in the shadows. As a recent study of these organizations notices, "in all kinds of historical situations and during various political and economic crises and in different political systems, workers have taken control of their workplaces. Yet this story of workers' self-administration is rarely told". ${ }^{2}$ In the case of Iran, there is only one monograph ${ }^{3}$ and a few articles published on the

1 Kargar, 25 Farvardin 1358/14 April 1979.

2 Dario Azzellini, "Introduction", in An Alternative Labor History: Worker Control and Workplace Democracy, ed. Dario Azzellini (London: Zed Books, 2015), 1. For other studies on workers' control, see Donny Gluckstein, The Western Soviets Workers' Councils Versus Parliament, 1915-1920 (London: Bookmarks, 1985); Immanuel Ness and Dario Azzellini, ed., Ours to Master and to Own: Workers' Control from the Commune to the Present (Chicago, IL: Haymarket Books, 2011).

3 Asef Bayat, Workers and Revolution in Iran: A Third World Experience of Workers' Control (London: Zed, 1987).

(C) PEYMAN JAFARI, 2021 | DOI:10.1163/9789004440395_011

This is an open access chapter distributed under the terms of the CC-BY-NC 4.o licepseman Jafari - 9789004440395 
showras. ${ }^{4}$ The lack of accessible sources has been an obvious obstacle, but state-centric approaches have rendered the showras invisible as well. Moreover, the revolutionary events leading to the fall of the monarchy in February 1979 and the Iran-Iraq War that started in September 1980 and ended eight years later have overshadowed the period in between, when the showras emerged. Finally, after the war ended, the ideological shifts following the fall of the Soviet Union further diminished the interest in the showras. ${ }^{5}$

The topic of this volume - labour relations and revolutions - offers an excellent opportunity to revisit the history of the showras, as they directly challenged and attempted to transform the established conditions and rules regulating labour during the Iranian Revolution. Making extensive use of newspapers, official documents, oil workers' leaflets and reports, memoirs and oral history, this chapter examines the experiences of showras in the Iranian oil industry during the period from 1979 to $1982 .{ }^{6}$ This industry is particularly interesting for two reasons. First, it is largely absent in previous literature about the showras in Iran. Second, given the strategic position of the oil industry in the country's economy, the showras in this sector played an essential role and had an impact beyond the local level, shaping political developments and national debates about labour relations.

Based on the international history of workers' councils, I discern five crucial features that define them. First, workers' councils are a form of collective organization based on direct democracy, which is expressed in debates and decision-making in assemblies, and in the election of delegates who are accountable and can be recalled. Second, the councils involve workers' selfactivity, expressed in the different forms of collective action through which they try to realize their demands. Third, workers' councils allow workers to exert some form of control over the production process (of services or products) and the administration of the workplace. Fourth, the councils can (but do not always) coordinate their activities within and beyond a specific economic sector or industry. Fifth, workers' councils have to relate to state power in one way

4 Shahrzad Azad, "Workers' and Peasant's Councils in Iran", Monthly Review, no. October 1980 (1980); Chris Goodey, "Workers' Councils in Iranian Factories”, MERIP Reports, no. June 1980 (1980); Saeed Rahnema, "Work Councils in Iran - the Illusion of Worker Control", Economic and Industrial Democracy 13, no. 1 (1992).

5 For an excellent discussion of the impact of the Iran-Iraq War on state-society relations, see Kaveh Ehsani, "War and Resentment: Critical Reflections on the Legacies of the Iran-Iraq War", Middle East Critique 26, no. 1 (2017).

6 The current chapter is partly based on an extensive chapter on the oil workers' showras in my doctoral dissertation, Peyman Jafari, "Oil, Labour and Revolution: A Social History of Labour in the Iranian Oil Industry, 1973-1983" (Leiden University, 2018). 
or another. Some not only challenge the economic power of capitalism in the workplace, but also project their power beyond it, by challenging the existing state and providing an alternative. These aspects, which collectively challenge capitalist labour relations at the workplace, sectoral and national levels, will be discussed in this chapter in order to evaluate the attainments, limitations and potential of the oil workers' showras.

The first part of the chapter provides an overview of the Iranian Revolution and the emergence of the showras. The second analyses the nature of labour relations on the eve of the revolution. The third part looks at the different ideological articulations of the showras. This is particularly important in the Iranian case, as workers' control is often associated with socialist, communist and anarchist ideas, while in Iran, Islam provided an additional important source of inspiration. The fourth part discusses the development of the conflict between the showras and the post-revolutionary state, identifying three phases. The subsequent final parts analyse the development of the showras' activities during these three phases.

\section{From Revolution to Showras}

The Iranian Revolution marked the return of oil workers to the national political stage after three decades of relative absence. Oil workers had played a pivotal political role in 1946-1953, when they had stood at the heart of a popular movement that demanded the nationalization of Iranian oil, which was controlled by the Anglo-Iranian Oil Company. That labour militancy receded, however, when Prime Minister Mohammad Mosaddeq was ousted in 1953 through a coup d'état orchestrated by the American and British secret services. ${ }^{7}$ During the following 25 years, Mohammad Reza Pahlavi, the Shah, consolidated his power by building a strong army, a modern secret service (the SAVAK), an enlarged bureaucracy and a patronage network around the court; and in the process became heavily dependent on American military and political support. He also embarked on an ambitious project of modernization within the framework of the White Revolution, which was launched in 1963, and spurred a rapid and uneven process of capitalist development leading to massive social, political and economic contradictions. Moreover, this development also "combined", pulling together traditional and modern features into

7 Ervand Abrahamian, The Coup: 1953, the Cia, and the Roots of Modern U.S.-Iranian Relations (New York: The New Press, 2013). 
new hybrid formations. ${ }^{8}$ A more elaborate discussion of these contradictions, and how they undermined the stability of the monarchy while making significant sections of the society receptive to revolutionary ideologies, falls beyond the scope of this chapter. ${ }^{9}$ There is no space here to discuss the complex causes and the dynamics of the revolution either, but instead this section provides an overview of the different stages of the revolution in order to contextualize the emergence of the showras. ${ }^{10}$

The revolutionary mobilization that led to the fall of the Shah in February 1979 unfolded in five stages, each marked by a particular combination of actions. ${ }^{11}$ The first stage, between June and December 1977, was marked by nonviolent mobilization of nationalist and liberal politicians, leftist authors and students, and lawyers and other professionals, who mainly wrote open letters and organized petitions. In October 1977, the death of Ayatollah Khomeini's son became a rallying point for the religious opposition, when ceremonies were organized in various cities. The second stage started in January 1978, after the daily paper Ettela'at published an article defaming Ayatollah Khomeini. In response, seminary students in Qom organized protests and were joined by $b a$ zaaris (shop owners and merchants in the bazaar) who shut down their shops, exerting enough pressure on the ayatollahs to end the students' classes. The clashes with the police left five people dead, and broadened "the revolutionary coalition from the intelligentsia to include a large segment of the ulama and the bazaar". ${ }^{2}$ Commemorating the "martyrs" of Qom 40 days later in accordance with Shia tradition started a cycle of protests every 40 days, as every

8 This reading is inspired by Leon Trotsky's analytical framework of "uneven and combined development". See S. Ashman, "Capitalism, Uneven and Combined Development and the Transhistoric", Cambridge Review of International Affairs 22, no. 1 (2009); Kamran Matin, Recasting Iranian Modernity: International Relations and Social Change (Abingdon, Oxon: Routledge, 2013).

9 For a more extensive discussion of this period, see Ervand Abrahamian, Iran between Two Revolutions (Princeton, NJ: Princeton University Press, 1982).

10 For the causes and dynamics of the Iranian Revolution, see Misagh Parsa, Social Origins of the Iranian Revolution, Studies in Political Economy (New Brunswick and London: Rutgers University Press, 1989); Mansoor Moaddel, Class, Politics, and Ideology in the Iranian Revolution (New York: Columbia University Press, 1992); Mohsen M. Milani, The Making of Iran's Islamic Revolution: From Monarchy to Islamic Republic (Boulder: Westview Press, 1994); Charles Kurzman, The Unthinkable Revolution in Iran (Cambridge, MA: Harvard University Press, 2004); Behrooz Ghamari-Tabrizi, Foucault in Iran Islamic Revolution after the Enlightenment (Minneapolis: University of Minnesota Press, 2016).

11 For a detailed discussion of these stages, see Ahmad Ashraf and Ali Banuazizi, "The State, Classes and Modes of Mobilization in the Iranian Revolution", State, Culture, and Society 1 , no. 3 (1985): 3-40.

12 Ibid., 7. 
commemoration-protest ended with casualties. This cycle had receded by June 1978 , as many participants became wary of the military violence.

August to September 1978 marked the third stage of the revolution, as the protest movement was revived when Islamist activists used the religious occasions during Ramadan - the month of fasting that started on 5 August 1978 to stage a series of protests. In August, several cinemas were set on fire, most notoriously in Abadan where at least 410 people were killed. ${ }^{13}$ Although agents of the Shah were blamed for this tragedy at the time, evidence points to the involvement of fanatic Islamist activists. Meanwhile, the regime had started to follow a confused strategy, alternating between repression and concession, and showing signs of panic as the political crisis deepened. While in late $\mathrm{Au}-$ gust 1978, the Shah had appointed Jafar Sharif-Emami to head a government of "national reconciliation", the military opened fire on demonstrators who had gathered in Zhaleh Square in Tehran on 8 September ("Black Friday"), killing 79 people. $^{14}$

Demonstrations continued, albeit with less intensity, but the locus of the protests shifted from the streets into the workplaces, and a mass strike - most importantly in the oil industry - became the hallmark of the fourth stage from September to December 1978. The fifth stage of dual power emerged in January and February 1979. As I have argued elsewhere, the strikes in the oil industry were an important launch pad for the emergence of three institutions that underpinned an alternative pole of authority parallel to the monarchy: the Committee for the Coordination of Strikes in the Oil industry, led by Mehdi Bazargan; the Council of the Islamic Revolution (CIR), which represented Khomeini's revolutionary authority; and the neighbourhood committees that were responsible for local fuel distribution and security, and were later transformed into komitehs that were loyal to Khomeini. ${ }^{15}$

The revolutionary situation continued in the three years following the February 1979 insurrection. The new state was consolidating its power, but was confronted with the mobilization of dissident political organizations, subaltern groups of women, ethnic minorities (most importantly the Kurds) and workers. In this period, workers' protests continued, although with greatly reduced intensity after the Iran-Iraq War started in September 1980, and the showras became a serious obstacle to the consolidation of the new state. This

13 Most reliable reports put the number of casualties somewhere between 410 and 45 .

14 Kurzman, The Unthinkable Revolution in Iran, 73.

15 Peyman Jafari, "Fluid History: Oil Workers and the Iranian Revolution", in Working for Oil: Comparative Social Histories of Labor in the Global Oil Industry, ed. T. Atabaki, E. Bini and K. Ehsani (Cham: Palgrave Macmillan, 2018). 
contestation ended in early 1982, when forces loyal to Ayatollah Khomeini monopolized state power, banned the remaining leftist organizations and repressed grassroots organizations, including the showras.

The workers' showras resulted from the confluence of two processes. First, following the February 1979 insurrection, the economy entered a period of crisis due to the strikes, political insecurity and a lack of raw materials; many enterprises shut their doors, and in many cases the owners fled the country. Others were purged by their workers or by revolutionary organizations. Second, the capitalist relations of production were challenged by radical ideologies, ranging from Marxist to Islamist.

As Asef Bayat has argued, in workplaces where the management had left or was severely weakened, there was a practical trigger for the creation of showras, often through the transformation of the existing strike or "inquiry committees", established to identify and purge members of the SAVAK, the Shah's secret service. In workplaces where the management had remained, showras emerged from a more combative attitude, derived from the revolutionary transformation of workers' consciousness. This revolutionary consciousness had two essential elements. First, the revolution had created a sense of ownership among workers regarding their workplace and society. This sense of ownership was not only expressed in terms of class, I should add, but was also articulated in terms of nation; particularly in the oil industry, which was regarded as a national asset. Second, many workers equated the old factory regime with the authoritarianism of the monarchy, and hence saw democratization of the workplace as an alternative. ${ }^{16}$

In the absence of genuine labour unions, the showras articulated oil workers' socioeconomic demands, particularly regarding wages and housing conditions, and campaigned to realize them. They were, however, much more than labour unions, due to their function as "workplace organisations that aimed to extend the control of labour over the organisation of production, limit the authority of management, and democratize the work environment". ${ }^{17}$ Their "elected executive committee represented all the employees of a factory (blue - and white-collar) and/or an industrial group, irrespective of trade, skill or gender. Their major concern was to achieve workers' control". 18

16 Bayat, Workers and Revolution in Iran, 109-112.

17 Asef Bayat, "Labor and Democracy in Post-Revolutionary Iran", in Post-Revolutionary Iran, ed. Hooshang Amirahmadi and Manoucher Parvin (Boulder, CO: Westview Press, 1988), 43 . 
Labour relations before the revolution were heavily shaped by the uneven and combined development in Iran, creating a situation in which traditional and modern labour relations existed at the same time, but were also drawn together into new combinations. The manufacturing sector was strongly bifurcated. Nearly 97 per cent of the manufacturing establishments were small sized, each employing fewer than 10 workers, and in total about 44 per cent of all the workers in manufacturing. While the remaining 3 per cent of the establishments were medium sized (10 to 49 workers) or larger (50 or more), they employed about 56 per cent of the manufacturing workers. ${ }^{19}$ Labour relations in the small establishments were mainly shaped by what Bayat has called "semi-craft management", referring to "the decentralized mode of production in small-scale, technically backward and organizationally simple units of production in which the worker-capitalist relations assume the appearance of the patron-client relation of the classic craft system". ${ }^{20}$ In most of the mediumsized establishments, which were often labour intensive, the "traditional management" prevailed. "In such units, direct control was dominant; there was no structural hierarchical mediating element between labour and capital ... The supervisors, the boss's hands, exerted an effective and extended control over the disciplinary process of the workshop, in terms of hiring, firing, wage increases, promotion, overtime, punishments and penalties". ${ }^{21}$ In the large establishments, the principles of "modern rational management" were partially used to regulate labour relations through "methods of organization and production, which, while raising the productivity of labour, at the same time sought the co-operation of the workforce [...], in the words of Burawoy, 'obscuring and securing surplus-value." "22

The oil industry, directly employing about 70,000 white-collar and bluecollar workers on the eve of the revolution, ${ }^{23}$ was one of the sectors where modern rational management was applied the most systematically, but only partially, to regulate labour relations. Using Richard Hyman's notion of industrial relations as a synonym, labour relations are defined here as the "processes

19 Farhad Nomani and Sohrab Behdad, Class and Labor in Iran: Did the Revolution Matter? (Syracuse, NY: Syracuse University Press, 20o6), 91.

20 Bayat, Workers and Revolution in Iran, 53.

21 Ibid., 55 .

22 Ibid., 56.

23 A similar number were employed through subcontractors active mainly in construction and distribution. 
of control over work relations". ${ }^{24}$ On the one hand, "work relations" are controlled by state policies regulating the capital-labour relations. As in many countries, the labour law in Iran played an important role in regulating these relations. The oil workers' struggles in the 1940s had contributed significantly to the societal pressures that had forced the government to introduce the labour law in 1946. On the other hand, labour relations are of course also regulated at the workplace or the industrial level, through what Michael Burawoy calls the "factory regime", referring to "the set of institutions that organize, transform, or repress struggles over relations in production and relations of production at the level of the enterprise". ${ }^{25}$

As I have explained more elaborately elsewhere, the factory regime in the Iranian oil industry before the revolution was a combination of what Burawoy calls "hegemonic" and "bureaucratic despotic" forms. ${ }^{26}$ In the former, the state and factory apparatuses are separated, but the state intervenes through laws and regulations to shape and constrain the action of the factory apparatus (for example, collective bargaining, trade unions and grievance settlements), which is geared towards the creation of consent. The "bureaucratic despotic" factory regime, based on repressive mechanisms of control, is characterized by the fusion of the factory and state apparatuses, and bureaucratic state intervention in the factory regime and the economy. ${ }^{27}$

The specific mechanisms of controlling the labour processes in the oil industry, which can be discussed here only very briefly, clarify why the labour relations there could be conceived of as hybrid. The first mechanism was the modern rational management discussed above. Most importantly, this created an internal market, a structural hierarchy within the workforce and an aligned system of rewards and punishments, which aimed to increase productivity while creating consent among the oil workers. The remuneration system was organized according to a well-defined job classification system that also regulated promotions. Hiring and firing were subject to bureaucratic rules, and there was an advanced system of educational and training

24 Richard Hyman, Industrial Relations: A Marxist Introduction (London: Macmillan, 1975), 12.

25 Michael Burawoy, Manufacturing Consent: Changes in the Labor Process under Monopoly Capitalism (Chicago, IL, London: University of Chicago Press, 1979), 110.

26 Jafari, "Oil, Labour and Revolution", 151-171.

27 Burawoy also identifies "market despotic" and "collective self-management" factory regimes. This is a simplified version of Burawoy's typology, limited to the main forms of factory regimes. See Michael Burawoy, The Politics of Production: Factory Regimes under Capitalism and Socialism (London: Verso, 1985), 12-13, 25-26, 85-121. 
institutions. The most important aspect, however, was an extreme hierarchy within the workforce that created a huge differentiation, and also conflicts, between white-collar and blue-collar employees, reflected in their wages and social, cultural, housing and health amenities. A similar differentiation existed between those directly employed by the National Iranian Oil Company (NIOC) and those employed by subcontractors. A system of collective bargaining and trade unions had also been established in the oil industry, expressing the Shah's will to create a corporatist system, but these were highly controlled by the state, which brings us to the "bureaucratic despotic" features of its labour relations.

The factory regime in the oil industry was not fully autonomous from the state, and had many authoritarian features. The oil workers' candidates for the trade unions and for the collective bargaining that took place every two years were vetted by the SAVAK. Agents of the secret service had also established a network of surveillance within the oil industry, creating fear among workers, who could face arrest, dismissal or transfer if they were reported as dissidents. The last factor contributing to the managerial control mechanism was the official ideology disseminated by managers and the NIOc's educational system and official publications, which promoted the ideas of meritocracy, competition and individual progress in the oil industry. However, there were also many internal contradictions here, as the idea of meritocracy and progress was contradicted by the political system of privilege for the supporters of the Shah. In 1975, for instance, the Shah introduced a one-party system, and obliged all civil servants - including the white-collar workers in the oil industry - to join the Rastakhiz Party. While some workers perceived this measure as repressive, others joined the party, only to discover that they were not allowed to play a meaningful role.

\section{Ideological Articulations}

The Iranian Revolution represented a major challenge to established labour relations in the oil industry - and elsewhere, of course. The showras became the most important institutions through which this challenge was organized in practice - as will be discussed in the final part - and articulated ideologically. Although the showras emerged more or less spontaneously, the influence of communist ideologies played an important function. The role of communist organizations in the creation of the showras was initially limited, in the sense that they had no preconceived plan to build the showras after the insurrection, but in many workplaces their members and sympathisers played 
a key role in founding and especially in sustaining them. ${ }^{28}$ Once the showras had been established, nearly all of the communist organizations supported them enthusiastically, however, without having a clear understanding of their potential, and without proposing a concrete strategy for them. Instead, the strategy was formulated only in very general terms as "communism". Having mainly debated issues around guerrilla warfare, imperialism, dependent development and other matters, it was rare to find any discussion about the historical and international experiences of workers' control in communist publications before the emergence of the showras. These organizations were therefore not well prepared and equipped to contribute to the debates that emerged.

The pro-Moscow Tudeh Party was the least enthusiastic about the showras. A major factor in Iranian politics in the 1940s and early 1950s, it was harshly repressed after the US and UK orchestrated coup d'état that toppled Prime Minister Mohammad Mosaddeq in 1953. The Tudeh Party lost much of its appeal to the younger generations, who thought it had failed to build resistance against the 1953 coup, and in the following two decades they grew impatient with its reformist approach to the Shah; an approach that in their view reflected the "revisionism" of the Soviet Union. After the insurrection, the party prioritized not the showras, but instead the creation of a national labour union. It opposed most of the strikes and accused other groups who did support them of ultra-leftism. ${ }^{29}$ The Tudeh Party argued - correctly - that labour unions and showras were two different things, and that both should be established, rather than substituting one for the other. In practice, however, this meant a strategy that favoured the unions. ${ }^{30}$ When the showras became a fact, the party tried to direct them into labour union activities rather than activities related to workers' control.

A wide range of communist organizations opposed the Tudeh Party's "opportunist" orientation, the largest of which was the Marxist-Leninist People's Fada'i Guerrilla Organisation (PFGO). Inspired by the Chinese and Cuban

28 Shahrzad Azad (a pseudonym of Valentine Moghadam) attributed a larger role to leftist organizations, arguing: "Left forces, in particular the Marxist-Leninist OIPFG and the progressive Islamic Mojahedin, played a major role in the formation and defence of these councils. In several factories in Teheran, the Daneshjooyan-e-Pishgam ('vanguard students' - associations of students throughout Iran that support the OIPFG) supported workers' strikes, assisted in their efforts to elect representatives to the councils, and cooperated in formulating the workers' political and economic demands." Azad, "Workers' and Peasants' Councils in Iran", 17.

29 Nameh-ye Mardom, 19 Khordad 1358/9 June 1979.

3о Nameh-ye Mardom, 3 Mordad 1358/25 July 1979. 
revolution, it advocated and conducted a guerrilla struggle against the Shah, but turned sharply towards the workers' movement after the insurrection, launching the journal Kar (labour) as its main publication. The editorial in its first issue, on 10 March 1979, stated:

It is our duty to take another step toward the advancement of the workers' movement with the publication of a special workers' journal ... Workers' collective struggles are organized through labour unions around economic demands ... but in order to be finally free, the working class has no other choice than to take political power, abolish private property of the means of production and destroy capitalism.

Thus, the PFGO promoted the creation of independent trade unions, but also called for workers' interference in management and ultimately the taking of political power through the showras and other grassroots organizations. Kar, for instance, argued: "If the showras act correctly and organize those who are capable and knowledgeable, and actively interfere with political affairs, they can develop into people's organizations for running the politics of the country". ${ }^{31}$ Similar views were espoused by the People's Mojahedin Organisation of Iran (PMOI), another guerrilla organization that had emerged before the revolution and that combined Islamic and Marxist ideas. This orientation was quickly derailed by the repression of the new regime and by the many splits within the PFGO and other communist organizations. ${ }^{32}$ Nevertheless, it is important to note that despite having a weak presence in the workplace during the revolution, the various leftist organizations grew during the oil strikes and in the months following the insurrection, and their presence in the showras became significant during 1979 .

There were different approaches to the showras among the Islamic forces within them. Many Muslim members of the showras were influenced by Shariati's Islamic liberation theology, which advocated the revolutionary transformation towards an Islamic classless society (jame'e-ye bitabaqeh-ye towhidi), and they were inspired by his reference to the concept of showras as an Islamic principle. ${ }^{33}$ Reflecting these radical views, the statutes of the Islamic showras

31 Kar, 13 Ordibehesht 1358/15 March 1979.

32 A detailed history of the Tudeh Party, the PFGO and its splits, and other communist organizations can be found in Maziar Behrooz, Rebels with a Cause: The Failure of the Left in Iran (London, New York: I.B. Tauris, 1999).

33 Ali Rahnema, An Islamic Utopian: A Political Biography of Ali Shariati (London: I.B. Tauris, 1998), 197 . 
proposed in June 1979 by the Society of the Islamic Workers' Showras - which was established to coordinate the activities of the showras - defined their task as the supervision and control of all the financial, personnel and cultural activities of factories. ${ }^{34}$

Another version of Islamism was represented by the maktabi (doctrinaire) ideology of those who supported Khomeini's line. ${ }^{35}$ This ideology supported the showras, finding justification in two verses of the Quran that refer to the need to arrive at decisions through consultation. Supporters of maktabi ideology opposed capitalism and "liberal" managers, but were zealously pro-Khomeini and supported his Islamic state, as well as the Islamic Republic Party (IRP), which was established on 20 March 1979. The contradictions of the maktabi ideology reflected the contradictions of Khomeini's political Islam as a form of populism that opposed capitalism, favoured Islamic justice (adl-e islami), voiced support for the mostazafin (downtrodden) and mobilized them; however, without challenging private property. ${ }^{36}$ Khomeini and the IRP tried to restrict the autonomy of the showras, Islamize them and subsume them within an authoritarian Islamic corporatist arrangement.

Not all of the Islamic ideologies were supportive or ambivalent towards the showras. Representing liberal Islam, Mehdi Bazargan's provisional government opposed the showras, as they disrupted the capital-labour relations of the free market. The conservative clerics who were aligned with the bazaaris were even more vehemently opposed. They became more vocal after 1982 and formed the right wing of the IRP. The existence of diverging ideological orientations within the showras inevitably led to conflicts. These conflicts in fact became a central point around which the post-revolutionary state-building project developed. In the following, I distinguish three phases in the development of the showras and their conflicts with the state.

34 Amalkard-e Dosaleh-ye Kanun-e Showra-ha-ye Islami-ye Kargaran Va Komiteh-ye Kargari [Performance of the Society of the Islamic Workers' Showras and the Workers Committee in the Last Two Years] (n.p.: Kanun-e Showra-ha-ye Islami-ye Kargaran, 1359/1982), 4.

35 For a similar distinction, see Siavash Saffari, Two Pro-Mostazafin Discourses in the 1979 Iranian Revolution (Berlin: Springer Science+Business Media, 2017). With regard to political factions in this period in the Islamic Republic of Iran, see Mehdi Moslem, Factional Politics in Post-Khomeini Iran, (Syracuse: Syracuse University Press, 2002), 6o-61.

36 With regard to the interpretation of Khomeini's political Islam (Islamism) as populism, see Ervand Abrahamian, Khomeinism: Essays on the Islamic Republic (London: I.B. Tauris, 1993); Peyman Jafari, "Rupture and Revolt in Iran", International Socialism Journal, no. 124 (2009). 
The state apparatus that emerged after the fall of the monarchy consisted of competing institutions with different ideological orientations that vied for political authority. Ayatollah Khomeini and his supporters exerted power through the Council of the Islamic Revolution (CIR), which functioned as the main legislative body until July 1980, a few weeks after the first parliament assembled. The neighbourhood komitehs and the Islamic Revolution Guards Corps (IRGC) provided armed support to Khomeini and the CIR.

In theory, executive power lay with the provisional government of Prime Minister Bazargan that was appointed by Khomeini on 1 February 1979, although its authority was regularly undermined by the political interventions of the komitehs, the IRGC and powerful clerics. Another centre of executive power was established after a presidential system was enshrined in the new constitution adopted in December 1979. Two months later, Abolhassan Bani-Sadr was elected president and remained in this post until he was ousted in June 1981 after a conflict with Khomeini. Within this field of competing centres of power, ultimate power resided with Khomeini in his position as the Supreme Leader, as envisioned in his doctrine of the velayat-e faqih, Guardianship of the Islamic Jurist. From the moment of their inception in the first months of 1979, the showras were confronted with this fragmented state apparatus. Their conflict developed in three distinctive phases in the subsequent three years.

The first phase in which the showras tried to create self-management and workers' control over production started immediately after the February 1978 insurrection, and continued until August 1978. Expressing what many workers expected, the oil workers' representatives believed "that the day after the revolution under the leadership of Imam Khomeini we will officially take over the control over the factories". ${ }^{37}$ However, when the showras did try to take control, both the provisional government and Khomeini and the IRP opposed them. The former tried to restore the pre-revolutionary labour relations based on technocratic managerial control by appointing new "liberal" managers in the establishments where the management had left and retaining them in the oil industry, while the latter encouraged the creation of Islamic Labour Associations (Anjoman-ha-ye Islami-ye Kar) to oppose the left, and supported the Islamic showras' opposition to the provisional government.

As the showras in the oil industry and elsewhere proliferated, the provisional government struggled to keep them in check. In early March 1979, it 
published a document that defined the nature and tasks of the showras as being separate from executive bodies such as the factory management. Referring to an Islamic principle, their task was defined as the "promotion of virtue and prevention of vice" (amr-e be ma'ruf, nahi az monkar). More concretely, they were to gather the workers' wishes and grievances, categorize them and pass them on to the officials, and enhance the unity between workers and the executive branches. ${ }^{38}$ The CIR went much further, introducing a law against "counter-revolutionary crimes" on 4 July 1979. Article 9 of this law directly targeted individuals who "disrupt the business in the country's workshops and factories or encourage workers to stop working or closing the workshop or factory", and specified a sentence of two to nine years for these "crimes". ${ }^{9}$ It was not until June 1980 that the authorities formulated regulations to give legal status to the showras; however, at this stage, what determined the practical functioning of the showras was not the laws and regulations, but the balance of power in the class struggle. In this respect, the interventions of the IRGC, the komitehs and the Islamic Labour Associations as tools for repression were much more significant.

The first phase ended in August 1979, when the new state conducted its first major assault against the opposition in Kurdistan. This marked the beginning of the crackdown on oppositional forces, including the showras. At the same time, the intra-state conflict continued and intensified at the highest managerial level of the oil industry. In late September 1979, Hassan Nazih, the chair of the NIOC and a close ally of Bazargan, was ousted after he had enraged pro-Khomeini supporters by criticizing the entanglement of religion and politics. ${ }^{40} \mathrm{He}$ was replaced by Ali Akbar Mo'infar, another close ally of Bazargan, who also became the first minister of oil a month later. The second phase started in September 1979, and was marked by the defensive posture of the showras as they came under heavy attacks from both Mo'infar and the pro-Khomeini forces. Following the occupation of the American Embassy in November 1979 by radical pro-Khomeini students, the provisional government resigned and the balance of political power shifted dramatically to the maktabis, who supported the existence of the showras while attempting to turn them into corporatist organizations, forcing out communists and PMOI sympathisers. The maktabis also clashed with the first elected president of the Islamic Republic, Bani-Sadr, who wanted to put technocratic managers at the head of factories. Thus, the maktabis in and outside the showras were fighting on two fronts;

$38 \quad$ Ettela'at, 19 Esfand 1357/10 March 1979.

39 This law can be viewed online at http://rc.majlis.ir/fa/law/show/98141 [13 November 2019].

40 Keyhan, 3 Mehr 1358/25 September 1979 and 7 Mehr 1358/29 September 1979. 
against the "liberal" president on the one side, and the communists and PMOI sympathisers on the other.

The third phase started with the Iran-Iraq War on 22 September 198o. The war was a decisive turning point, as it destroyed many oil facilities and forced thousands of oil workers to move out of the oil-producing region that bordered Iraq. Moreover, the war served as a distraction from the social conflicts, encouraged nationalism and allowed the state to crack down on the opposition in the name of national unity. The repression increased dramatically after June 1981, when President Bani-Sadr was ousted. The weakened showras in the oil industry were banned in early 1982 .

Having discussed the overall development of the conflict between the showras and the state in the period from 1979 to 1982 , we can now look at how they organized and tried to transform the labour relations in this period.

As one journalist aptly observed in early March 1979, the emergence of grassroots organizations in the oil industry posed a serious challenge to the statebuilding process after the collapse of the monarchy: "After winning the battle on the streets of Tehran and ousting first the Shah and then [his last] Prime Minister Bakhtiar, Ayatollah Khomeini's new Islamic regime faces crucial weeks as it tries to strengthen its grip on the government. Nowhere will the battle for control be more difficult and vital than in the oil fields where $\mathrm{Na}$ tional Iranian Oil Co. is gearing up to resume exports". ${ }^{41}$ A month later, Time Magazine reported:

In dusty, steamy Abadan ... an air of normality appears to have returned. But life is anything but normal inside the world's largest refinery.... Members of the workers' council argue interminably. Said one welder after a particularly boisterous session: "Nobody can make any decisions. All anybody does is talk". Convinced that they were the dominant force in ousting the Shah, the oil workers feel that they are being neglected by the revolutionary government. They are insisting on $50 \%$ to $100 \%$ wage

41 Roger Vielvoye, “New Nioc Chief Faces Explosive Situation”, Oil \& Gas Journal, no. 5 (1979): 93. Shapour Bakhtiar was a longstanding member of the National Front, who was appointed prime minister by the Shah as a conciliatory move. This move failed, however, after he was condemned by other leaders of the National Front and was rejected by Khomeini. 
increases and are threatening to walk out if they do not get them. Members of the workers' council have been demanding sweeping changes in management. ${ }^{42}$

The establishment of oil workers' showras posed a challenge not only to Khomeini's Islamist populism and Bazargan's Islamic liberalism, but also to the technocratic-managerialist order that Nazih wanted to restore in the oil industry. In Abadan, the strike committee in the refinery had taken effective control over the production before the February 1979 insurrection. The workers had organized the "Committee of the Guards of the Oil Industry" to protect the refinery, and had introduced a five day, 40-hour working week. ${ }^{43}$

After the insurrection, the strike committees in the Abadan Refinery invited all the workers to participate in general assemblies in order to elect the representatives of the showras. Higher wages, better and cheaper housing, retirement benefits, participation in management and the purge of senior ancien régime employees were the most important demands made by the Abadan oil workers. ${ }^{44}$ This experience was replicated in the oil fields and in other refineries (Tehran, Shiraz, Tabriz, Kermanshah and Isfahan). At the same time, the workers in the Razi petrochemical complex near Abadan established their own showra. The showras of the Abadan Refinery and the Razi petrochemical complex represented both blue-collar and white-collar workers, and in both locations there was a central showra, consisting of representatives of those from the different departments.

In Abadan, the showras had become so powerful that the entire board of directors resigned on 18 April in protest at their interference in the management of the plant, and only returned two days later after Nazih's intervention. ${ }^{45}$ Describing the situation in Abadan, an Associated Press journalist reported that Iran's oil industry was in the hands of "radical workers who demanded a major role in deciding who gets their products and at what price. Marxists are actively recruiting among them, although they remain a minority". ${ }^{46} \mathrm{Up}$ until late April 1979, the showra exerted considerable control over production and administration in the Abadan Refinery, and introduced a 4o-hour working week, but its role gradually changed into participation after the provisional

42 Bruce Van Voorst, "Another Crude Awakening in Iran after the Revolution, Oil Workers Gush Discontent", Time 113, no. 23 (1979): 43.

43 Kar (Minority), Bahman 1367/January-February 1989.

44 The New York Times, 6 March 1979.

45 Ettela'at, 3o Farvardin 1359/19 April 1979 and 1 Ordibehesht 1359/21 April 1979.

46 Associated Press, 25 February 1979. 
government appointed a new management. Nevertheless, interference with the management's affairs continued and created tensions. ${ }^{47}$

In some of the refineries, the showras took over almost total control of production and administration. This happened, for instance, in the Pars Oil Company (refinery) near Karaj, which was Iran's first and only private refinery at the time..$^{48}$ After the insurrection, its 503 employees established a showra of seven people and seven sub-committees, and drafted a list of demands: nationalization of the refinery by NIOC, the dismissal of foreign employees, pay increases, a housing allowance, lowering of the mortgage interest rate to 2 per cent and a meeting place for the showra. Confronted with an unwavering director, the showra organized a general meeting in May and called for the nationalization of the Pars Oil Company. When this move did not produce the desired result, the showra changed track. In a general meeting on 20 June 1979, it decided to sell the products itself and use the income to pay wages and salaries. The Pars Oil Company showra held a meeting with the production managers to coordinate the takeover, and established a "committee for the provisional administration of the refinery", consisting of the showra members and two technicians. After the general meeting of the showra ratified this decision, it took over the refinery on 24 June, hanging banners on the main gate and inside the refinery reading, "National Oil Company of Iran: Karaj Refinery". In a following step, the showra stopped the sale of products, stockpiling them in the depots, and sent two of its members to negotiate a merger with the NIOC. The provisional government finally stepped in on 13 August 1979, authorising the Ministry of Industry and Mines to appoint a director for the company and rolling back workers' control. ${ }^{49}$

In the Tehran (Rey) refinery, pipelines and depots (Tehran Refinery in short), communist workers were gradually manoeuvred out of the common syndicate that had been established during the strikes in late 1978. It became dominated by those who were either supporters of the IRP, or took a neutral or conciliatory stance towards it. In response, leftist workers started to establish showras in different departments of the refinery. ${ }^{50}$ Three main showras were established at general assemblies that elected their members. The Showra of Maintenance Employees represented workers in the turnery, transport, precision tools, electrics, general and pump repair departments, together with the barrel-making factory and a number of others. The Showra of Shift Employees represented

$47 \quad$ Kar (Minority), Bahman 1367/January-February 1989.

48 Kayhan, 3 Dey 1339/24 December 196o.

49 See http://rc.majlis.ir/fa/law/show/10498o [13 November 2019].

50 Kar (Minority), Bahman 1367/January-February 1989. 
the shift workers in the control rooms, lubricant and bitumen factories, the electricity, water and steam powerhouses, the loading stations, etc. The United Showra emerged through the unification of the showras of the engineers, the administration, and the safety and security services. At a general assembly in the Tehran Refinery, these three showras nominated their own candidates, who were elected into the Showra of the (Tehran) Refinery Employees. ${ }^{51}$

A further step was taken towards greater coordination among the showras in late February or early March 1979, when the white-collar workers in the NIOC headquarters in Tehran initiated the establishment of the General Showra of the Oil Industry Employees (Showra-ye Sarasari-ye Karkonan-e San'at-e Naft), bringing together representatives from the showras in the oil, gas and petrochemical industries all over Iran. It was agreed to elect one representative for every 1,00o employees, bringing the membership of the General Showra of the Oil Industry Employees in theory up to 65 to $70 .{ }^{52}$ In practice, however, it started its activities with 47 elected members. ${ }^{53}$ On 17 March 1979, the General Showra of the Oil Industry Employees created a number of subcommittees dealing with: 1) projects; 2) contact with the NIOC chair Nazih; 3) technical affairs; 4) personnel and accounting; 5) gathering advice from employees; 6) wages and salaries; 7) social affairs of the employees; 8) cultural activities; 9) fuel distribution; and 10) communication with the production units. ${ }^{54}$ Most of those on the showra were members or sympathisers of leftist organizations, but despite these organizations' ideological differences, the members cooperated relatively well. Until the autumn of 1979, the General Showra of the Oil Industry Employees was involved in the recruitment and dismissal of employees, their wage and job classification, and the election of department heads by general assemblies. Workers had taken over a number of positions, including the head of the security guard, the head of the administration and the head of the transport department. ${ }^{55}$

Another important showra in the oil industry was the General Showra of the Ahwaz Oil Employees, which had 6o representatives from the various showras

$5^{1} \quad$ Yadollah Khosrowshahi, "Tashkilat-e Mostaghel-e Kargari Va Zarf-e Tashakolpaziri-ye Kargaran-e Iran Dar Moghe'iyat-e Konuni [Independent Worker Organizations and the Possibility to Organize Workers in Contemporary Iran]", Kargar-e Tab'idi, no. 36 (January 1997): 17 .

$5^{2} \quad$ Kar (Minority), Bahman 1367/January-February 1989.

53 Peygham-e Emruz, 22 Ordibehesht 1357/12 May 1979.

54 Peygham-e Emruz, 23 Ordibehesht 1357/13 May 1979.

55 Khosrowshahi, Tashkilat-e Mostaghel-e Kargari Va Zarf-e Tashakolpaziri-ye Kargaran-e Iran Dar Moghe'iyat-e Konuni [Independent Worker Organizations and the Possibility to Organize Workers in Contemporary Iran], 17. 
in the oil fields, the production units, the maintenance departments and the administrative offices in and around Ahwaz. In the first months of its activity, it managed to force the authorities to reduce the inequalities between bluecollar and white-collar workers. The blue-collar workers, for instance, were given air-conditioning, which - unlike their white-collar colleagues - most were unable to afford by themselves. The Ahwaz showra also gave support to workers in the drilling companies, who were demanding the nationalization of their companies. ${ }^{56}$

Fighting against Repression: September 1979 to September 1980

When the balance of power dramatically shifted to the pro-Khomeini forces between August and November 1978, the showras retained their collective decision-making function but lost much of their effective control over production and management. They nevertheless continued to intervene in the management's activities. The "frontier of control" within the oil industry thus shifted, mainly under the influence of the national political conflicts discussed earlier. ${ }^{57}$ After the attacks on the grassroots organization had intensified in August 1979, and Nazih was ousted as chair of the NIOC in September, the repression of the showras increased, and they faced a state that had become controlled to a greater extent by the pro-Khomeini forces. This second phase of the showras' activities lasted until the Iran-Iraq War started in September 1980.

In this phase, the activities of the showras in the oil industry became completely defensive, as they faced repression and attempted to maintain some level of control by interfering in matters of management over a number of specific issues. First, the showras resisted the provisional government's decision in late September 1978 to cancel Thursdays being considered as part of the weekend. The management of the Abadan Refinery issued its own decree to announce this new policy, but the representatives of the refinery workers immediately published a statement opposing the new schedule for working hours, "because it was introduced without consultation with the workers' representatives", and announced that they would continue working in accordance with the previous schedule. The workers in the Aghajari oil field also refused to work on Thursdays, and a group of "militant oil workers in Ahwaz" issued

\footnotetext{
$5^{6}$ Interview with Kobra Qasemi, 8 August 2017, Amsterdam.

57 Carter Goodrich, The Frontier of Control (New York: Harcourt, Brace and Howe, 1920).
} 
a statement calling on their colleagues to similarly boycott the new schedule. ${ }^{58}$ On 30 September, workers at the Shiraz Refinery went on strike after a week of go-slow protests. ${ }^{59}$ According to Mansour Sadri, head of the NIOc's statistical staff at the time, high absenteeism by blue-collar workers and lower-ranking white-collar staff became prevalent during this period. ${ }^{60}$ Thanks to their protests, the oil workers scored a major victory in December 1979, when a 40-hour working week and time off based on the weekend including Thursday and Friday was agreed by the CIR and announced by Minister of Oil, Ali Akbar Mo'infar.61

A few weeks earlier, another victory had been achieved by radical oil workers who had demanded the cancellation of oil exports to the US. In its session of 12 November 1979, the CIR decided to cut off these exports. ${ }^{62}$ Although the occupation of the American Embassy was the main trigger, Mo'infar explained that this measure had been taken at the request of "a large number of our compatriots, especially the noble workers of the oil industry". The Islamic Labour Showra of the oil workers of Kharg Island then issued the following statement:

We are all your soldiers, Khomeini; we await your order, Khomeini. Immediately after the midnight news broadcast by the radio and having been informed of the orders of the great idol-breaker and the brave and diligent Imam of the Islamic Revolution of Iran, Imam Khomeini ... we stopped the oil flow to the tanker, Northern Line, which was loading at quay number 14 of Kharg Island to be transported to the US. ${ }^{63}$

The Abadan Refinery was one of the main sites of continuing showra activity, including collective decision-making. In February 1980, the showra of the northern Abadan Refinery workers issued a statement demanding that any

58 Peykar, 16 Mehr 1358/8 October 1979. Khabar-e Kargar, Dey 1358/December 1979-January 1980.

59 Peykar, 23 Mehr 1358/15 October 1979.

6o US Embassy in Tehran to Secretary of State, Washington DC, 29 October 1979; Document Number 1979TEHRAN11423; Electronic Telegrams, 1979; Central Foreign Policy Files; General Records of the Department of State, Record Group 59; National Archives at College Park, Maryland.

61 Kar, 28 Azar 1358/19 December 1979.

62 This came after pro-Khomeini students occupied the American embassy in Tehran on 4 November 1979. Many workers, including in the oil industry, saw the ensuing radicalized political atmosphere as an opportunity to step up their activities and demands. For Khomeini and his supporters, this anti-imperialist move created an opportunity to sideline the liberals and the left.

63 "Iran Cuts off Oil Exports to USA", in в вс Summary of World Broadcast (14 November 1979). 
change in the grades of employees should only be made after it had been informed and consulted. It also issued a statement condemning any workers who met with the management without the showra's consent. ${ }^{64}$

On 15 April 1980, the Islamic Showra of the Abadan Oil Employees organized a general assembly that was attended by a few thousand workers. At the end of the gathering, the general assembly adopted a resolution, which started with the words, "In the name of the God of the mostazafin [downtrodden]" and stated the following demands:

1) condemnation of all measures undermining the showras;

2) the unconditional release of four arrested oil workers;

3) a televised debate between Minister of Oil Mo'infar and representatives of the oil workers' showra;

4) dismissal of Mo'infar;

5) legal pursuit of those violating Article 36 [the right of the accused to be heard in a competent court] and 37 [the principle of innocence until proven otherwise];

6) lifting the ban on Payam [the journal of the Abadan oil workers];

7) attention paid to oil workers' social and economic conditions;

8) an invitation to President Bani-Sadr to visit the Abadan Refinery for negotiations.

The declaration ended with the statement that the showra of the Abadan Refinery took no responsibility if the demands were ignored. ${ }^{65}$ Yet another example is provided by the Islamic Showra of the Distribution Employees of the Oil Industry, representing about 12,00o workers. This was one of the strongest showras in which religious forces were dominant. ${ }^{66}$ On 15 December 1979, it held a general assembly to elect its representatives. ${ }^{67}$ After it had decided to purge ten managers on 6 July 1980, Mo'infar retaliated by demanding the suspension of ten of its members, but the conflict quickly escalated as the showra issued a statement, demanding in turn the dismissal of Mo'infar. ${ }^{68}$

64 Kar-e Jonub, 3 o Esfand 1358/20 March 1980.

$65 \operatorname{Kargar}(s K), 3$ Ordibehesht 1359/23 April 1980.

66 The influence of religious workers in the showra is acknowledged in leftist literature by references such as "the showra was labelled Islamic due to the illusions of workers about Khomeini".

67 Khabar-e Kargar, Dey 1358/December 1979-January 1980. Bahram Burbur, Nasser Manuchehri, Ali Asghar Heydari Moqadam, Ali Tarfaq, Kiyumars Najmabadi and Shamsaldin Raqami were elected to the central showra. A number of others, among them one woman, were elected as representatives in the regional showras.

Kar (Minority), Bahman 1367/January-February 1989. 
The Tehran Refinery showras regularly interfered in the running of the refinery and participated in the weekly management meetings, which inevitably created tensions. A turning point was reached after the showra members, who were concerned with the income gap between the management and ordinary workers, approached the financial department and demanded to see the salary list; a request that was met. In response, officials promptly arrested a number of the showra's members in the summer of 1980 to draw a line in the sand. In the Isfahan Refinery, the majority of the workers attended the general assembly on 26 November 1979, where the following demands were made:

1) the refinery director Mir-'Azimi will be discharged and replaced by Aghasi 'Alaqband and Haj Hashem Alhosseini;

2) the heads of accounting, administration and the fire brigade will be sacked;

3) all contracts of the refinery will be continued until the end of the month but no payments should be made till the showra has made a final decision;

4) from 27 November, all employees of the refinery must use the refinery transport service and the use of refinery cars is no longer allowed.

Worried about the power of the showra, Ayatollah Ali Qodusi, the national prosecutor, sent a representative to the Isfahan Refinery to condemn the actions. When Mo'infar attempted to visit the refinery to deal with the problems, a number of workers spread the rumour that he would be physically attacked, forcing the minister to stay away. ${ }^{69}$

Although the showras had lost much of their direct control, the examples above demonstrate that they were still intervening in the management of companies. The American Embassy staff asked its top ranking contacts the question: "How are decisions made at NIOC?" They were surprised by how many did not know:

NIOC is compartmentalized to the point that few offices are aware of what is going on down the hall. Ghobad Fakhimi, director for distribution and pipelines, and formerly a close associate of Nazih, suggested that decision-making was something of a negative veto process. Either a policy is adopted by consensus, or an issue remains unresolved. It can be carried over indefinitely, or until the blocking faction became convinced or fatigued. ${ }^{70}$

69 Khabar-e Kargar, Dey 1358/December 1979-January 1980.

70 US Embassy in Tehran to Secretary of State, Washington D.C., 29 October 1979; Document Number 1979TEHRAN11423; Electronic Telegrams, 1979; Central Foreign Policy Files; 
Purging (paksazi) the oil industry of managers and employees who had supported the Shah or had worked for the SAVAK was perhaps the most important issue in which oil workers' showras interfered in the operations of the management. Although this had been on the agenda of oil workers since the insurrection, its importance increased during the second phase of the showras' activities. There were multiple reasons for the nearly obsessive emphasis on the need to purge the oil industry. First, the element of revenge played a significant role, as many showra members had first-hand experience of obstruction and repression by some of the managers during the oil strikes, and by SAVAK members before the revolution. Second, there was a symbolic meaning attached to the purges: revolutionary change in the workplace was closely associated with the change in management. The need to be rigorous in this respect was moreover fed by the fear of a coup. This fear was triggered by the 1953 coup and the counter-revolution in Chile in 1973, both of which were part of oil workers' political memory. Third, as the showras lost control in other aspects, the attempt to remove high-ranking managers became the main mechanism to assert their own power within the industry and send a message to the new political establishment.

One of the grievances the showras had harboured against Nazih during the period from February to September 1979 was his reluctance to move ahead with the purges, as he was trying to retain experienced managers based on the argument that they were needed in order to sustain productivity. In response, the showras and the Islamic labour associations increasingly acted on their own, pushing NIOC to take action or threatening to exclude those accused of links with the former regime from the workplace. In October 1979, the Showra of the Employees of the Oil Industry in Ahwaz published a list of 70 employees who they accused of having collaborated with the SAVAK and foreign companies, and of having undermined the oil workers' strikes. Frustrated by the government's lack of action, the showra sent the accused a letter stating the nature of the allegations and the consequences (dismissal for 43 of them, retirement for 17 and suspension for three months for the remaining 10). In response to this form of action, the CIR installed a committee of five men on 15 December 1979 to deal with the purges, and Mo'infar called on employees to forward any accusations to this committee. ${ }^{71}$ However, the oil workers in turn complained that the committee was acquitting suspects, and had even allowed some of those who had been sacked under Nazih to return. ${ }^{72}$

General Records of the Department of State, Record Group 59; National Archives at College Park, Maryland.

71 Khabar-e Kargar, Dey 1358/December 1979-January 1980.

72 Mojahed, 29 Khordad 1359/19 June 1980. 
Therefore, the showras continued to act independently, and purged a number of high-ranking employees. On 16 December 1979, the central showra in the Abadan Refinery issued a statement announcing the dismissal of 25 employees accused of collaboration with the SAVAK, and ordered the showra of the refinery's security guards to revoke their employee cards. The showra of the communication workers was similarly ordered to cut off their telephone lines, and the showra of the accounting employees to stop their wages until the central showra determined the amount of the allowance they would be paid. ${ }^{73}$

By early 1980, barely a week would pass without one of the oil workers' showras issuing a statement demanding that one or other manager should be purged. ${ }^{74}$ By 30 June 1980, the "purge committee" had given its verdict on 485 of the 700 investigated employees, who were either sent into retirement or sacked. ${ }^{75}$ In early August 1980, the oil workers' showras of Tabriz, Shiraz and Tehran issued a list of demands in relation to the purges, which included that the purge committee had to justify the dismissal of employees. ${ }^{76}$ These interventions illustrate the amount of control a showra could still exert in the administrative activities of a refinery.

While these examples mainly concern the defensive actions taken by the showras, they were also able to develop an offensive approach to the issue of nationalization, making use of the political opportunity that emerged in November 1979. The demand for nationalization was mainly raised by the 4,370 Iranian workers in foreign drilling companies. The strike committee of drilling workers that had emerged during the oil strikes in late 1978 opposed radical protests, but many of the workers - mostly those with leftist sympathies - wanted to establish a showra. ${ }^{77}$ The komitehs, which had been formed in some oil fields by Islamist oil workers and local activists, constituted a more serious obstacle to independent action, as they were cooperating with the state officials. After months of protests by oil workers, the komitehs in the drilling companies were dissolved and replaced by showras, which took over the firms after the foreign management had left and then formulated a number of demands: fighting unemployment, the actual nationalization of all drilling companies and their subcontractors, and the establishment of a national drilling company. On 18 July 1979, the showras of the workers in the different drilling companies united in a common organization, the Association of the Showras of Drilling

73 Document 267890206, IRDC archives, Tehran.

74 Ettela'at, 11 Farvardin 1358/31 March 1980.

75 Ettela'at, 9 Tir 1359/30 June 1980.

76 Enqelab-e Islami, 20 Mordad 1359/11 August 1979.

77 Kar, 18 Mordad 1358/9 August 1979. 
Companies and Services (Kanun-e Showraha-ye Haffariva Khadamat-eJanebi), and started coordinating their protests. ${ }^{78}$ These protests were not only driven by nationalist sentiments, but also by the fear of unemployment, as the foreign companies were planning to move their equipment out of Iran.

Encouraged by the occupation of the American Embassy on 4 November 1979, the Association of the Showras of Drilling Companies and Services issued a statement calling for the NIOC to directly employ the drilling staff and to pay their wages during unemployment. They further asked for the drilling companies to be prevented from moving their equipment out of Iran - which, the statement claimed "resulted from our [the workers] blood but has fallen into the hands of imperialist capitalists" - and the "immediate establishment of the national Iranian drilling company". Taking the matter into their own hands, the showras of the SedIran and SedCo drilling companies issued a statement on 8 November 1979, announcing the confiscation of these firms. ${ }^{79}$ Another month of protests continued before the government conceded and nationalized the drilling companies; establishing the National Iranian Drilling Company (NIDC) on 22 December 1979, and marking the final step in bringing the oil industry under total Iranian ownership.

In addition to the foreign drilling companies, the Fluor Company - which was involved in the construction and maintenance of the refineries in Tehran, Shiraz, Tabriz and Isfahan - was also targeted for nationalization by its 3,00o workers, who had organized a showra. ${ }^{80}$ Having protested since February, this showra also seized on the opportunity provided by the anti-imperialist wave following the occupation of the American Embassy, and organized protests to demand nationalization. These actions were supported by the showra of the Isfahan refinery, and intensified after Fluor announced the dismissal of 700 employees on 11 December 1979. When Fluor tried to transfer some of its property to the Bandar Abbas port, in order to ship it to the US, it was confiscated by a group of workers. However, the government stepped in, sacked two members of the showra and asked for official permission from the Islamic court in Isfahan for the transfer to proceed. ${ }^{81}$

Losing the Fight: October 1980 to January 1982

The third and final period in the activity of the showras in the oil industry started with the Iran-Iraq War in September 1980 and ended with the outlawing of

78 Peykar, 1 Mordad 1358/23 July 1979.

79 Ettela'at, 22 Aban 1358/13 Novemer 1979.

8o Ettela'at, 22 Azar 1358/13 December 1979.

81 Khabar-e Kargar, Dey 1358/December 1979-January 1980. 
the organizations in early 1982. Before the start of the war, the showras had been entrenched in a battle with the government and the management of the NIOC over wages and working conditions, and more importantly, about the nature and extent of their power. Despite the political divisions among the showra members, especially between the leftist workers and the maktabis, there was a great deal of common ground among them. In many instances, the maktabi and other religious members of the showras had demanded workers' participation in the management of production and administration, and had resisted pressure; first from the provisional government of Bazargan in 1979 and subsequently from President Bani-Sadr in 1980. The war not only fundamentally shifted the balance of power between the showras and the state in favour of the latter, transforming their conflict into a battle for survival, but also shifted the balance between the leftist and the maktabi members of the showras in favour of the later. The war dramatically increased the proclivity of maktabis to equate independent action with "counter-revolution", and made many workers receptive to nationalist and religious calls to fully support the state.

By the start of the war, the oil workers' showras had lost much of their power in terms of their ability to interfere in management affairs. This loss was initially not total, however, as the following example illustrates. After the start of the war, the management of the Tehran Refinery ordered that petrol was to be refined at a lower quality than its usual octane number of 88 , in order to reduce the production time. The showra members opposed this measure, however, arguing that it would be harmful to car engines. When the management refused to accept their argument, the showra instructed workers in the laboratories not to approve petrol samples if their octane rating was lower than 88 , and to record a much lower number than the actual value in order to deceive the management, thereby tricking them into raising the octane number. ${ }^{82}$ In many cases, moreover, the management did not feel confident enough to act without the showras' consent, and the showras continued to organize protests, such as the one on 13 April 1981 when about 600 workers in the Tehran Refinery gathered in its canteen to protest against housing problems. The protest ended with an open letter issued by the refinery's showra to the Prime Minister:

If it is the right of every individual to compare himself with his neighbour, he will feel he is living in an unjust system if he observes [big differences in] housing, health, food and clothing conditions. If it is the right of every

82 Hazhir Pelaschi, "Dar Khoruskhan-e Khun Tabaram Mikhanam - Goftogu Ba Ali Pichgah [Interview with Ali Pichgah]”, Manjaniq, no. 2 (Dey 139o, December 2011-January 2012). 
revolutionary worker to compare his conditions before and after the revolution, he will say that there is continuity in the administrative system if he sees no changes in his conditions. In other words, the employees of the oil industry have been the victims of wrong and anti-revolutionary policies of officials such as Nazih and Mo'infar.

The open letter reiterated that if oil workers had made an important contribution to the victory of the revolution, then they should have the right to be part of the government subsequently. 83

Overall, however, the start of the war rang the death knell for the showras. As illustrated above, the role of those that survived in the first year after the war became mainly limited to organizing protests and issuing statements about working and housing conditions. The decisive move against the showras in the oil industry was made on 30 January 1982, when the state disbanded the Showra of the Oil Industry Employees. About 140 of its members were arrested. Some of them were executed, and others were sentenced to long terms of imprisonment and were not allowed to return to work after their release. A number of factors contributed to the eventual demise of the oil workers' showras. First, the war damaged many oil facilities, and displaced the population in the southwestern region - including many oil workers - causing the showras in the region to implode. At the same time, however, new showras emerged among oil workers who had fled the region, particularly Abadan, as they established the Showras of the War-torn Oil Industry Employees (Showra-ha-y-e Sarasariye Karkonan-e Jangzadeh-ye San'at-e Naft) in the cities where they resettled. The name of these organizations reflected the communist orientation of their leaders, rather than their actual functioning, which was focused on campaigning for their members' most urgent needs: housing and employment. They had no involvement in the management of the oil industry.

Second, the war created the opportunity for the state to dramatically increase the level of repression against the showras; arresting and later executing some of their members. In early 1981, for instance, three representatives of the Showras of the War-torn Oil Industry Employees were arrested in Tehran. ${ }^{84}$ In Shiraz, four Hezbollahi vigilantes attacked the general meeting of the "wartorn" oil workers on 27 May 1981. The IRGC acted as the main repressive force, arresting showra members, but also the members of the leftist organizations

83 Kar (Minority), 2 Ordibehesht 136o/22 April 1981.

84 Mohammad Mazra'ekar, "Etesab-e Kargaran-e Naft Dar Sal-e 57 va Zamineha-ye An. Bakhshe Dovvom [the Oil Workers' Strike in 1978-1979 and its Causes. Part Two]", Kargare Komonist, no. 8o (20 March 2008). 
that supported them. Whilst the IRGC operated from the outside, the Islamic Labour Associations (Anjoman-ha-ye Islami-ye Kar) operated as the IRP's workers' organizations inside the workplaces. In the first year after the insurrection, they opposed the "liberal" managers and leftist workers through the propagation of "Islamic values" ${ }^{85}$ They became increasingly tools of surveillance and state propaganda, however, as they reported dissident workers to the management, organized prayers and recruited workers for the war.

Third, the state and the NIOC management purged dissident workers. On 14 July 1980, before the war had begun, CIR had already ratified a law allowing the establishment of "purge committees" (hey'at-ha-ye paksazi), consisting of representatives of the provincial governor, the revolutionary prosecutor, the factory management, the ministry of labour and an elected employee. ${ }^{86} \mathrm{In}$ the following two months, over 150 purge committees were established, sacking not only managers and state officials, but also thousands of teachers and employees. This created an opportunity for upward mobility into managerial positions for hundreds of Islamic activists. ${ }^{87}$ The purges, which had been advocated by the oil workers' showras, were now used by the state to target dissident oil workers, especially those in the showras. As table 9.1 illustrates, the overwhelming majority of the nearly 5,00o employees purged from the oil industry by the end of 1983 had been targeted for "acts against the Islamic Republic" and "immoral behaviour".

Fourth, the state introduced a legal framework that was meant to make the showras devoid of any meaningful autonomy, "Islamize" them and incorporate them into an authoritarian corporatist framework. On 30 June 1980, the CIR approved a legal bill that defined the aims of the Islamic showras as "the creation of a spirit of cooperation and solidarity between all the employees and the management in order to improve and develop the affairs of each unit".88 This law aimed to turn the showras - now allowed to only function under the name of Islamic Labour Showras - into consultative bodies, and gave the ministry of labour a considerable amount of control over them through its right to appoint the members of the "supervision committee" (hey'at-e nezarat). These committees consisted of two representatives of the regional Islamic showras, two representatives of the regional managers and a representative of the

85 Bayat, Workers and Revolution in Iran, 102.

86 Asef Bayat, "Workers' Control after the Revolution", MERIP Reports, no. 113 (March-April 1983): 20, http://rc.majlis.ir/fa/law/show/99ogo [13 November 2019].

87 Said Amir Arjomand, The Turban for the Crown: The Islamic Revolution in Iran (New York: Oxford University Press, 1988), 144. 


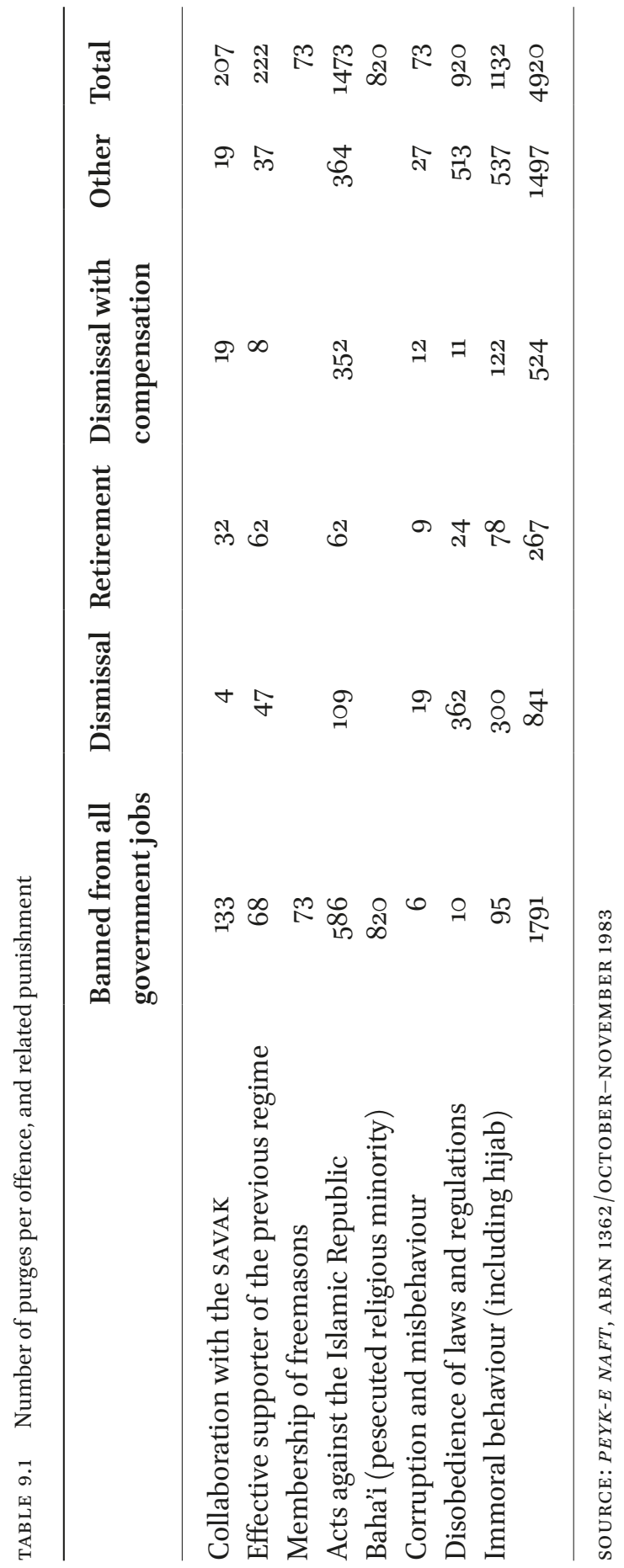


Ministry of Labour. Furthermore, membership of a showra was only open to those supporting the Islamic Republic, and all the employees of an enterprise, including workers and managers, could participate in the elections. The founding of Islamic showras in large industries such as oil and steel also had to be approved by the government. This law was not ratified by the parliament until 20 January 1985 , due to the resistance from the maktabi members of the showras, but it merely legalized the practices that had been established since 1982 .

\section{Conclusion}

As I have argued in this chapter, the oil workers' showras posed a serious challenge to pre-revolutionary labour relations in the Iranian oil industry, which combined "hegemonic" and "bureaucratic despotic" elements. In order to evaluate the success and failure of this challenge, it is useful to summarize here how the oil workers' showras performed in the five areas of activity that workers' councils have developed over time, as explained at the beginning of this chapter.

The showras were relatively successful in terms of creating the structures and processes through which workers could participate in discussions and decision-making in their workplace. The structures and processes, organized through elections, were relatively democratic and contributed to the development of a radical democratic ethos. This was, for example, reflected in the manner in which representatives of different ideological currents collaborated. In the second area, the showras also had some important attainments, as they managed to involve a significant number of oil workers in their struggles. These struggles managed to achieve, initially at least, higher wages, better housing conditions, easier mortgages, a 40-hour working week with a two-day weekend and an improvement in the status of contract workers. Yet many of these measures were gradually revoked, especially after the Iran-Iraq War started in September 1980. The most concrete and important achievement of the showras' struggles was the reduction of the material and social gap between white-collar and blue-collar workers, which had been a major source of grievance among the latter.

The showras failed, however, in other areas. They were least successful in creating and maintaining control over production and administration. In the initial months after the fall of the monarchy, the showras managed to exert a considerable degree of control over production and administration, but this was gradually lost. Yet this loss was not total, as they continued to interference or participate in the appointment of the management, and its policies 
regarding hiring and firing. Nevertheless, even this level of control was taken away by force during the increasing state repression and destruction following the start of the Iran-Iraq War. One reason for this was the lack of technological knowledge among oil workers, and hence their dependence on the technicians and managers to run the industry. This problem was not a fundamental obstacle, however, as many among the white-collar employees - including engineers and administrators - sympathized with the showras. The most decisive factor in the showras' failure was the state, which used force and appointed technicians and administrators who opposed workers' control.

Lack of coordination was another weak point of the showras, and in this regard, subjective factors played a larger role. The intra-factory coordination was often well-arranged, but intra-industry coordination was often lacking. The General Showra of the Oil Industry Employees had been established, but it was centred around Tehran and functioned more on paper than in reality as a wellstructured body. More importantly, there is little evidence that the oil workers' showras coordinated their activities with the showras of other workers at the city or the national level. Although repression contributed to the situation, the lack of preparedness among the showras' representatives and the divisions between the leftist organizations also played an important role. For similar reasons, the showras - unlike, for example, the workers' councils during the Russian Revolution - did not attempt to extend their activities by involving subaltern groups and establishing what Marx called, "a working class government".89 The lack of a unified strategy among the showras, together with the repressive power of the post-revolutionary state, had made such a strategy unfeasible.

As a result of this negative balance sheet, the oil workers' showras were not able to change the labour relations in their industry. They did seriously challenge the hegemonic-bureaucratic-despotic factory regime of the oil industry by challenging the authoritarian rules and structures, introducing workers' self-management and democratic decision-making processes, and partly abolishing the hierarchical divisions between white-collar and blue-collar workers. They also contributed to the redrafting of the labour law that, due to its many progressive elements, became opposed throughout the 198 os by the political factions that favoured the free market. However, the hegemonic-bureaucraticdespotic labour relations at the workplace level were re-established in the years following the revolution, within a larger framework of authoritarian, populist corporatism at the national level.

89 Karl Marx, "The Civil War in France", in Karl Marx and Friedrich Engels, Collected Works (London: Lawrence \& Wishart, 1986 [1871]), 333-334. 
Thus the phenomenon that Marcel van der Linden has discussed as the "paradox of revolution" in the introduction to the current volume was repeated during the Iranian Revolution. Nevertheless, three important conclusions can be drawn from this experience. First, the showras demonstrated that workers have the potential to create democratic organizations in an authoritarian context, and to establish some level of control over the production and administration in their workplace. As in other historical cases, a revolutionary crisis allowed workers to take practical measures to realize this potential, even if only for a short time.

Second, the showras in Iran demonstrated that certain interpretations of Islam also provide ideological articulations for workers' control, even though this articulation contained contradictions that surfaced in the showras' relations with the state; contradictions that were not that different from the ones apparent in communism at different historical moments. ${ }^{90}$ These contradictions led the Islamist, maktabi workers to support the state in its attempt to repress the non-Islamic currents, but at times this brought them into conflict with the Islamist state as well, when it tried to reduce the showras to corporatist organizations under its control. These contradictions were buried under the economic and social ruins of the Iran-Iraq War, and the call for unity became louder than the protests against the state's assault on the showras. This throws up an interesting "what if" question that warrants more research into Islamist currents among labour activists during the Iranian Revolution: would the conflicts between these currents and the Islamist state have developed into a serious clash, if the Iran-Iraq War had not started?

The third conclusion relates to the war itself. The experience of the Iranian Revolution demonstrates the historical co-occurrence of revolution, war and state building, and underlines the importance of its impact as an explanatory factor in the shifting balance between revolution and counter-revolution.

\section{Bibliography}

Abrahamian, Ervand, Iran between Two Revolutions (Princeton, NJ: Princeton University Press, 1982).

Abrahamian, Ervand, Khomeinism: Essays on the Islamic Republic (London: I.B. Tauris, 1993). 
Abrahamian, Ervand, The Coup: 1953, the Cia, and the Roots of Modern U.S.-Iranian Relations (New York: The New Press, 2013).

Amalkard-e Dosaleh-ye Kanun-e Showra-ha-ye Islami-ye Kargaran Va Komiteh-ye Kargari (n.p.: Kanun-e Showra-ha-ye Islami-ye Kargaran, 1359/1982).

Arjomand, Said Amir, The Turban for the Crown: The Islamic Revolution in Iran (New York: Oxford University Press, 1988).

Ashman, S., "Capitalism, Uneven and Combined Development and the Transhistoric", Cambridge Review of International Affairs 22, no. 1 (2009): 29-46.

Ashraf, Ahmad, and Ali Banuazizi, "The State, Classes and Modes of Mobilization in the Iranian Revolution", State, Culture, and Society 1, no. 3 (1985):3-40.

Azad, Shahrzad, "Workers' and Peasant's Councils in Iran", Monthly Review, no. October 1980 (1980): 14-29.

Azzellini, Dario, "Introduction", in An Alternative Labor History: Worker Control and Workplace Democracy, ed. Dario Azzellini (London: Zed Books, 2015), 1-3o.

Bayat, Asef, "Workers' Control after the Revolution", MERIP Reports, no. 113 (MarchApril 1983): 19-34.

Bayat, Asef, Workers and Revolution in Iran: A Third World Experience of Workers' Control (London: Zed, 1987).

Bayat, Asef, "Labor and Democracy in Post-Revolutionary Iran", in Post-Revolutionary Iran, ed. Hooshang Amirahmadi and Manoucher Parvin (Boulder, CO: Westview Press, 1988), 41-55.

Behrooz, Maziar, Rebels with a Cause: The Failure of the Left in Iran (London, New York: I.B. Tauris, 1999).

Burawoy, Michael, Manufacturing Consent: Changes in the Labor Process under Monopoly Capitalism (Chicago, IL, London: University of Chicago Press, 1979).

Burawoy, Michael, The Politics of Production: Factory Regimes under Capitalism and Socialism (London: Verso, 1985).

Ehsani, Kaveh, "War and Resentment: Critical Reflections on the Legacies of the IranIraq War", Middle East Critique 26, no. 1 (2017): 5-24.

Ghamari-Tabrizi, Behrooz, Foucault in Iran Islamic Revolution after the Enlightenment (Minneapolis: University of Minnesota Press, 2016).

Gluckstein, Donny, The Western Soviets Workers' Councils Versus Parliament, 1915-1920 (London: Bookmarks, 1985).

Goodey, Chris, “Workers' Councils in Iranian Factories”, MERIP Reports, no. June 1980 (1980): 5-9.

Goodrich, Carter, The Frontier of Control (New York: Harcourt, Brace and Howe, 1920). Hyman, Richard, Industrial Relations: A MarxistIntroduction(London:Macmillan, 1975). Jafari, Peyman, "Rupture and Revolt in Iran", International Socialism Journal, no. 124 (2009): 95-163. 
Jafari, Peyman, "Fluid History: Oil Workers and the Iranian Revolution", in Working for Oil: Comparative Social Histories of Labor in the Global Oil Industry, ed. T. Atabaki, E. Bini and K. Ehsani (Cham: Palgrave Macmillan, 2018), 69-98.

Jafari, Peyman, "Oil, Labour and Revolution: A Social History of Labour in the Iranian Oil Industry, 1973-1983" (Unpublished dissertation, Leiden University, 2018).

Khosrowshahi, Yadollah, "Tashkilat-e Mostaghel-e Kargari Va Zarf-e Tashakolpaziriye Kargaran-e Iran Dar Moghe'iyat-e Konuni”, Kargar-e Tab'idi, no. 36 (January 1997): 11-28.

Kurzman, Charles, The Unthinkable Revolution in Iran (Cambridge, MA: Harvard University Press, 2004).

Marx, Karl, "The Civil War in France", in Karl Marx and Friedrich Engels, Collected Works, Vol. 22 (London: Lawrence \& Wishart, 1986), 307-359.

Matin, Kamran, Recasting Iranian Modernity: International Relations and Social Change (Abingdon, Oxon: Routledge, 2013).

Mazra'ekar, Mohammad, "Etesab-e Kargaran-e Naft Dar Sal-e 57 va Zamineha-ye An. Bakhshe Dovvom", Kargar-e Komonist, no. 80 (20 March 2008): 9-10.

Milani, Mohsen M., The Making of Iran's Islamic Revolution: From Monarchy to Islamic Republic (Boulder: Westview Press, 1994).

Moaddel, Mansoor, Class, Politics, and Ideology in the Iranian Revolution (New York: Columbia University Press, 1992).

Moslem, Mehdi, Factional Politics in Post-Khomeini Iran, (Syracuse: Syracuse University Press, 2002).

Ness, Immanuel, and Dario Azzellini, ed., Ours to Master and to Own: Workers' Control from the Commune to the Present (Chicago, IL: Haymarket Books, 2011).

Nomani, Farhad, and Sohrab Behdad, Class and Labor in Iran: Did the Revolution Matter? (Syracuse, NY: Syracuse University Press, 20o6).

Parsa, Misagh, Social Origins of the Iranian Revolution, Studies in Political Economy (New Brunswick and London: Rutgers University Press, 1989).

Pelaschi, Hazhir, "Dar Khoruskhan-e Khun Tabaram Mikhanam - Goftogu Ba Ali Pichgah", Manjaniq, no. 2 (Dey 139o, December 2011-January 2012): 6o-64.

Rahnema, Ali, An Islamic Utopian: A Political Biography of Ali Shariati (London: I.B. Tauris, 1998).

Rahnema, Saeed, "Work Councils in Iran - the Illusion of Worker Control”, Economic and Industrial Democracy 13, no. 1 (1992): 69-94.

Saffari, Siavash, Two Pro-Mostazafin Discourses in the 1979 Iranian Revolution (Berlin: Springer Science + Business Media, 2017).

Vielvoye, Roger, "New Nioc Chief Faces Explosive Situation", Oil \& Gas Journal, no. 5 (1979): 93 . 